\title{
Improving the Quality of Services for the Elderly Referred To 22-Bahman
}

\section{Hospital: An Action Research}

\author{
Amiri Delui $\mathrm{M}^{1}$, Abedi H.A², Tahmasebi S ${ }^{3}$, Ebrahimi N4, ${ }^{*}$ Sadeghmoghadam L ${ }^{5}$
}

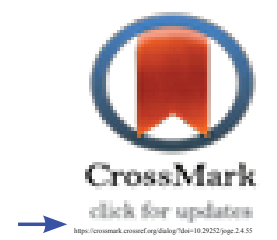

1- Department of Social Health, Mental \& Aging Nursing, Faculty of Nursing, Social Development and Health Promotion Research Center, Gonabad University of Medical Science, Gonabad, Iran.

2- PhD in Nursing, Nursing and Midwifery Faculty, Isfahan (Khorasgan) Branch, Islamic Azad University, Isfahan, Iran.

3- PhD in Nursing, Nursing and Midwifery Faculty, Shahrekord Branch, Islamic Azad University, Shahrekord, Iran.

4- Pediatrics Nursing Department, Nursing Faculty, Gonabad University of Medical Sciences, Gonabad, Iran.

5- Phd. Department of Social Health, Mental \& Aging Nursing, Faculty of Nursing, Social Development and

Health Promotion Research Center, Gonabad University of Medical Science, Gonabad, Iran (Corresponding

Author) Email: 1s_moghadam@yahoo.com

\section{Abstract}

Introduction: Along with an increase in the prevalence of chronic diseases, demographic changes are regarded as a challenge in the health care systems for the elderly. To improve the quality of health care, the communication between health care providers and older patients should be taken into consideration. This study was conducted to improve the quality of services for the elderly referred to 22-Bahman Hospital.

Method: This is a qualitative action research study. The study population included 11 elderly patients admitted to the different wards of 22-Bahman Hospital. Their age range was between 65 to 89 . In the first stage after obtaining informed consent, data was collected and recorded purposefully by using an unstructured interview in 30 minutes. Qualitative content analysis was used to analyze data.In the second stage, a focus group consisted of 12 members of the health care team was formed and their attitudes in providing optimal health care as well as constrains and problems of the elderly were proposed and recommended solutions were evaluated. In the third stage, a workshop was held and evaluation was performed in different stages.

Results: The content of interviews was analyzed and classified into the following concepts: 1. Problems of nursing care quality.2. The lack of participation in decision-making.3. The lack of respect.4. Limited resources to improve the welfare of patients.5. Worries about treatment payment .6. Nutritional issues. The following problems were reported by health care team in the focus group: 1.Crowded wards. 2. Shortage of nurses .3. Hearing problems and amnesia in the elderly.4. Reduced learning.5.Patients without a companion.6. Patients' dialect.

Conclussion: The results indicated that training nurses and health care team for aging process and physical and mental needs of this vulnerable group is necessary. So, action research is an effective way which influences the manner and incentives of health care team. The participation of elderly patients in action research improves health care services and consequently reduces the dissatisfaction of elderly patients.

Keywords: Quality improvement, Services, Elderly, Hospital, Action research.

Received: 3 June 2017 Accepted: 9 June 2018

\begin{tabular}{|l|l|l|}
\hline \multicolumn{3}{|c|}{ Access this article online } \\
\hline Website: \\
Www.joge.ir
\end{tabular}


ارتقاء كيفيت خدمت رسانى به سالمندان مراجعه كننده به بيمار ستان آموزشى YY بهمن كناباد:

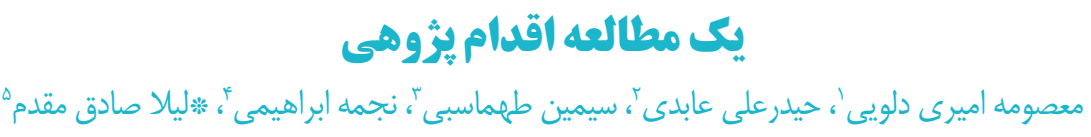

ار- كارشناس ارشد يرستارى سلامت جامعله، كروه آموزشى يرستارى سلامت جامعل، روان و سالمندى، دانشكده يرستارى، مركز تحقيقات توسعه اجتماعى و ارتقاء سلامت، دانشاه علوم بزشكى كناباد، كناباد، ايران.

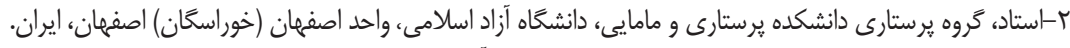

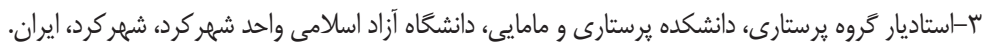

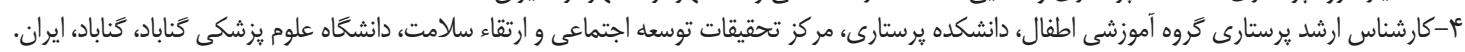

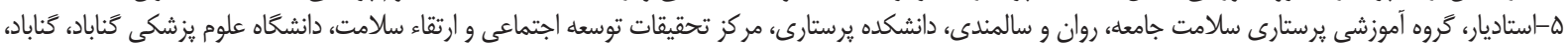

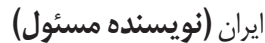

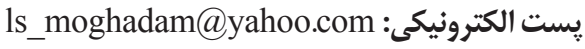

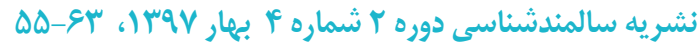

\section{جكيده}

مقدمه: تغييرات جمعيتى با افزايش شيوع بيماريهاى مزمن، به عنوان يك جالش سيستمهاى مراقبت هاى بهداشتى درمانى براى

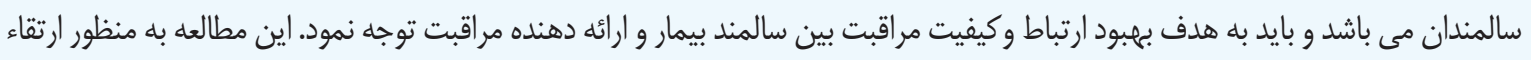
كيفيت خدمت رسانى به سالمندان مراجعه كننده به بيمارستان آموزشى كابرهمن كناباد انجام شد.

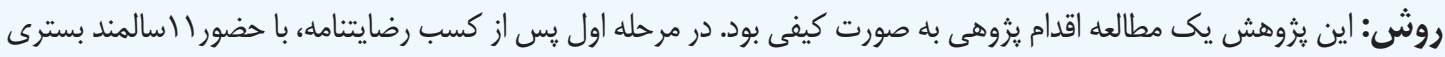

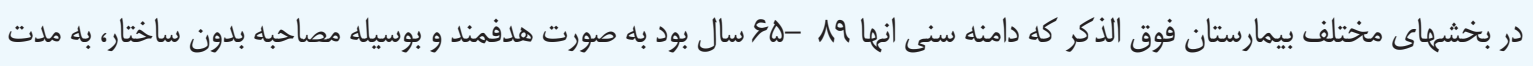

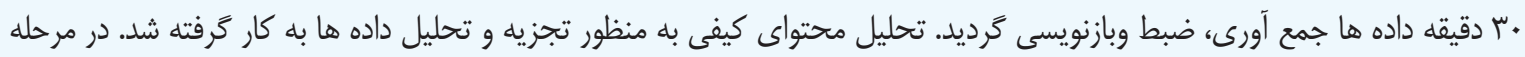

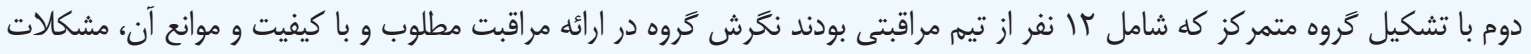

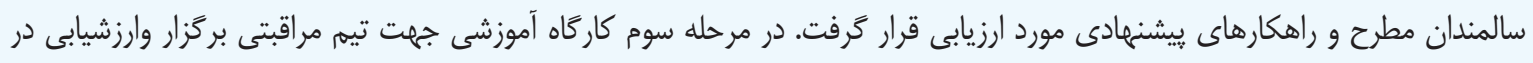
مراحل مختلف انجام كرديد.

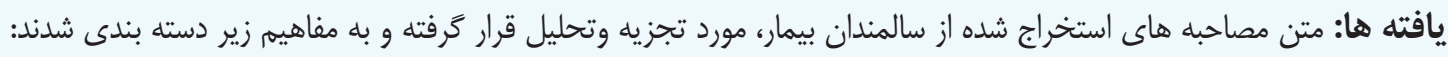

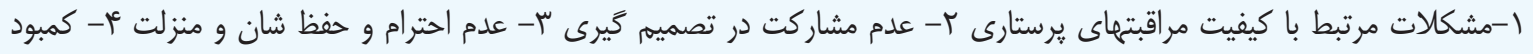

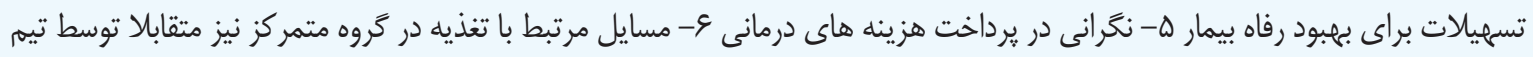

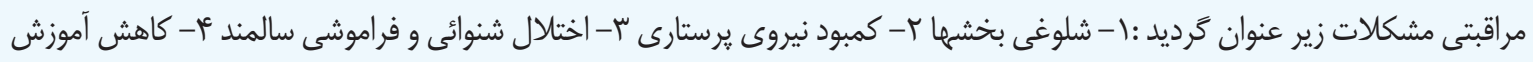

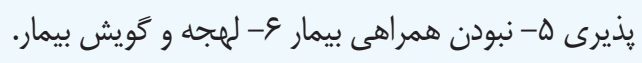

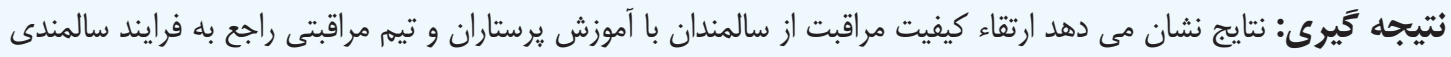

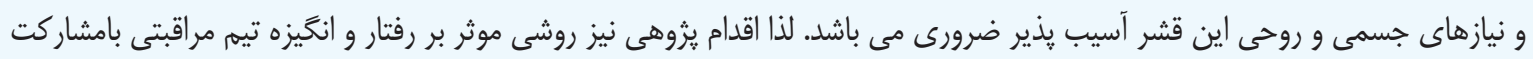

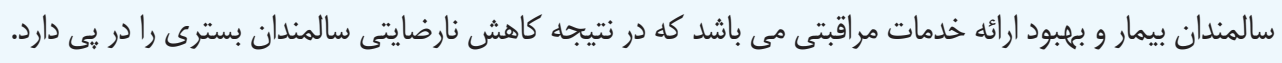
كليدوازه ها: ارتقاء كيفيت، خدمت رسانى، سالمندان، بيمارستان، اقدام يزوهى.

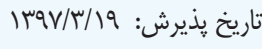

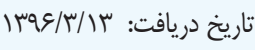




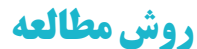

اين مطالعه با استفاده از روش اقدام يثوهى به صورت كيفى

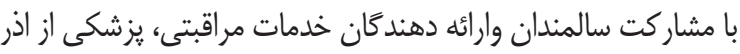

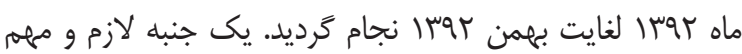
از فرايند اقدام يثرهى مشاركتى، مستند سازى دقيق و عينى نحوه نخاه به مشكل توسط افرادى است كه مشكل در زندگى شان وجود

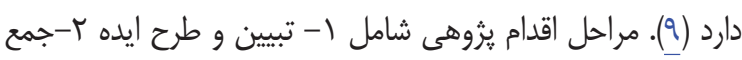

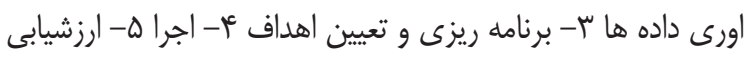

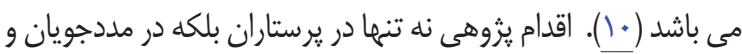

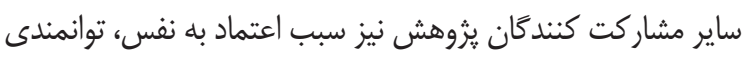

و اختيار مى شود (11). (1).

انتخاب نمونه ها بر اساس روش نمونه گيرى هدفمند با بالي

$$
\text { شر ايط زير بوده است: }
$$

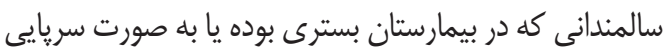

جهت دريافت خدمات مراقبتى، يزشكى به بيمارستان مراجعه كرده

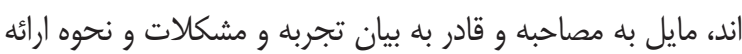

خدمات در حين بسترى يا مراجعه به بيمارستان هستند.

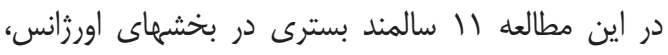
داخلى، جشم درمانغاه تخصصى و دياليز شركت داشتند و با انجام مصاحبه بدون ساختار، يادداشت بردارى هاى در عرصه، اشباع

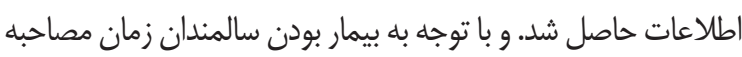

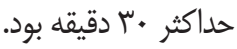
مصاحبه با بيمارانى كه مسئله مورد مطالعه را تجربه كرده اند بود

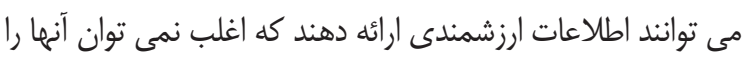

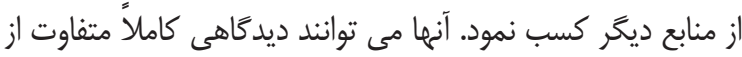

آنجهه قبلاً وجود داشته عرض نمايند (I) (I). مصاحبه با يك سوال كلى در مورد مشكلات آنان در نحوه دريافت خدمات مراقبتى يزشكى شروع و سوالات بعدى نيز در مورد

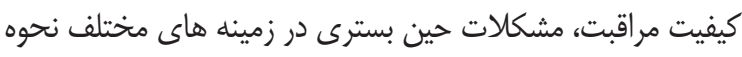

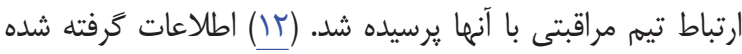

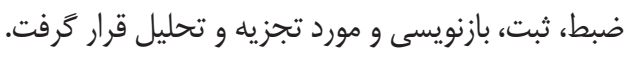

\section{1. 1.}

در اين مطالعه || (لمالمند شركت داشتند كه مشخصات آنها

$$
\text { در (جدول () آورده شده است. }
$$

امروزه حدود + V ميليون نفر از جمعيت جهان را افراد بالاى

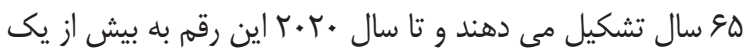
ميليارد نفر خواهد رسيد (1). وزارت بهداشت ايران در سال r. +.r

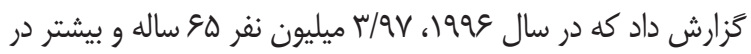
ايران زندكَى مى كردند كه و/ع درصد كل جمعيت كشور رات راتشكيل

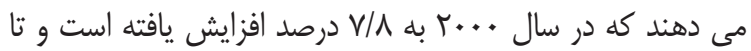

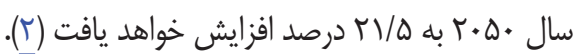
تغييرات جمعيتى با افزايش شيوع بيماريهاى مزمن، به عنوان يك קالش براى سيستمهاى مراقبتهاى بهراشتى براى سالمندان

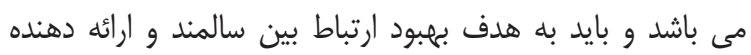

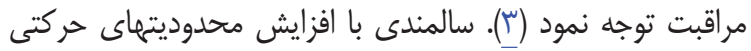

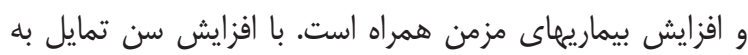

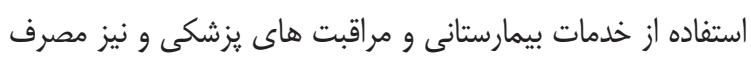

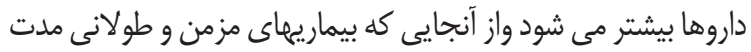

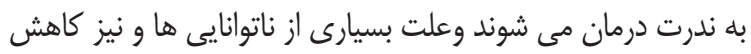

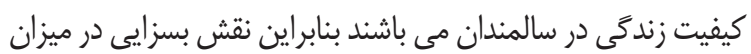

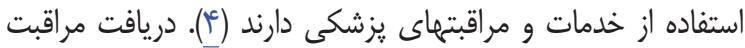

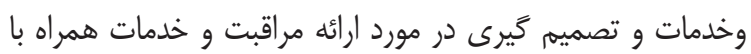

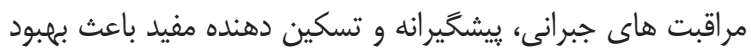

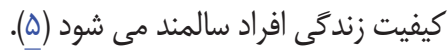

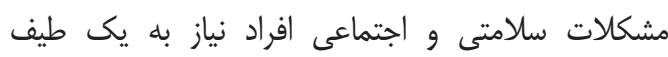
كَترده اى از خدمات در طى يك مدت طولانى دارد عدم

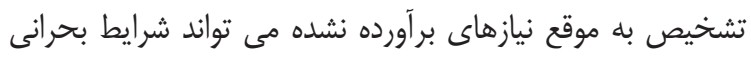

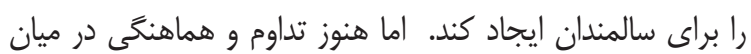

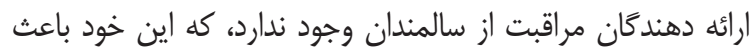

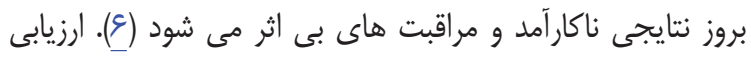

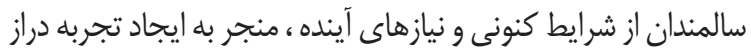
مدت از مشكلات جسمى مى شود كه افزايش تقاضا براى مراقبت إنى

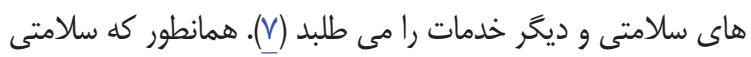
حق اساسى هر انسان و يكى هدف اجتماعى است، تمام دولت ها و حكومت ها موظف به تأمين سلامت تمامى افراد در هر سنى أنى

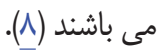
مطالعات زيادى در ايران راجع به مشكلات، تجربيات و نيازهاى سالمندان بسترى و مراقبان انها در بيمارستان هاى سطح بهان

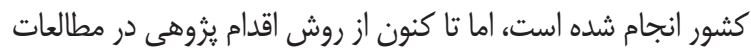
ذكر شده با مشاركت سالمندان و ارائه دهندكًان مراقبت ها استفاده نشده است، بنابراين مطالعه حاضر با هدف ارتقاء كيفيت خدار خداء رسانى به سالمندان مراجعه كننده به بيمارستان آموزشى بr بهمن 
جدول (ا ويزَيهاى جمعيت شناختى سالمندان شركت كننده در مطالعه

\begin{tabular}{|c|c|c|c|c|c|}
\hline بخش بسترى & وضعيت تاهل & تحصيلات & سن & جنسيت & رديف \\
\hline اورزانس & متاهل & دييلم & SD & زن & 1 \\
\hline داخلى & متاهل & بى سواد & VA & مرد & r \\
\hline داخلى & متاهل & ابتدايى & $v^{r}$ & مرد & r \\
\hline קشم & بيوه & بى سواد & AV & زن & f \\
\hline اورزانس & متاهل & فوق دييلم & 99 & زن & $\Delta$ \\
\hline داخلى & متاهل & بى سواد & ve & زن & $\varepsilon$ \\
\hline داخلى & متاهل & بى سواد & $\wedge$. & زن & v \\
\hline جشم & متاهل & بى سواد & 19 & مرد & $\wedge$ \\
\hline دياليز & متاهل & دييلم & SV & مرد & 9 \\
\hline دياليز & بيوه & بى سواد & $\wedge \varepsilon$ & مرد & 1. \\
\hline درمانخاه تخصصى & متاهل & ابتدايى & $\varepsilon_{\Delta}$ & مرد & 11 \\
\hline
\end{tabular}

جه يرستار و يزشك كه توى بيمارستان بود بالاى سرش اوملن كه حسابى وحشت كرده بودم آخرش هم كه فوت كرده.

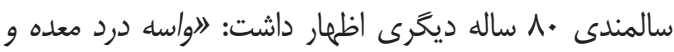
ضعف و بى حالى أ روزه كه بسترى هستهم از همون روز اول يك كاي مريض بدحال اين طرف تختم بود كه فوت كرد. اين بنده خداي

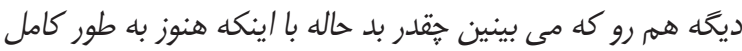

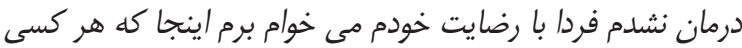

$$
\text { مياد مى ميره ... ". }
$$

نخرانى جهت نداشتن همراهى نيز براى سالمندان يا كمى

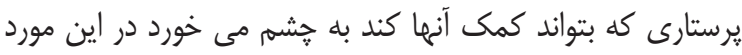
سالمندى 19 ساله بيان داشت: سالمندى NV ساله ديخرى اظهار داشت :"اكه همر اه داشته باشمر يا كسى باشه كه كمكم كنه مى تونم برم دستشويى اما وقتى درخواست مى كنم جون نمى تونم تند راه برم سريع برام لحن مى يارند تو اتاق همر كه تنها نيستهم واقعاً جلو بقيه

$$
\text { بيماران اين كار براى من خيلى عذاب آوره". }
$$

r- عدم مشار كت در تصميم گيرى در روند مراقبت و درمان

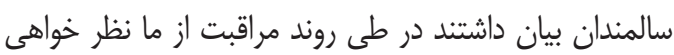

$$
\text { نمى كنند و اجازه تصميه گيرى نمى دهند. }
$$

سالمندى AV ساله ديخرى اظهار داشت : ل دجار بى اختيارى ادرار شده بودم مى خواستند واسم سوند بذارن از اينكه جند تا دانشجو

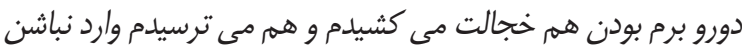

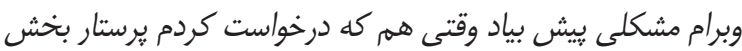

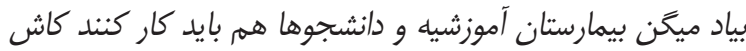

$$
\text { مى تونستم خودم حق انتخاب داشته باشه." }
$$

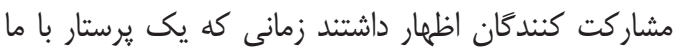
سلام و احوال يرسى مى كند، احساس ارزشمندى مى كنند و وقتى به صحبت هاى ما گوش مى كنند متوجه مى شويه كه ما براى آنها
گس از تجزيه و تحليل، دست نوشته ها به مفاهيم زير طبقه

1- مشكلات مرتبط با كيفيت مراقبت هاى يرستارى

يرستاران بيشترين ميزان مراقبت مستقيم أب ساعته را به بيماران ارائه مى نمايند و نقش بسزايى در ارائه مراقبت با كيفيت مطلوب به سالمندان بسترى دارند. يرستاران بايد ترس بيماران ران با ارائه توضيحات در مورد برنامه هاى درمانى با ايجاد اطمينان و دلسوزى بكاهند. تشويق به يادآورى و مرور زندگى به هنگًام برقرارى خط وريدى يا تعويض پانسمان مى تواند موجب انحراف فكر گردد.

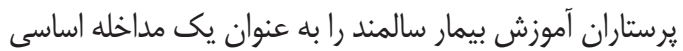
در تمام برنامه هاى مراقبتى بايد مد نظر قرار دهند ودر صورت عدم

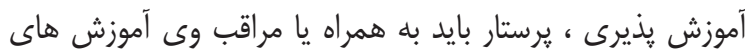
لازم را بدهد.مراقبت با كيفيت مطلوب يكى از مهمترين مسايلى بهري مى باشد كه اكثر بيماران سالمند خواستار ان بودند و به نحوى از ارايه مراقبت ناراضى بودند. سالمند 99 عنوان كرد: لامنو واسه عكسبرداى برده بودند وقتى

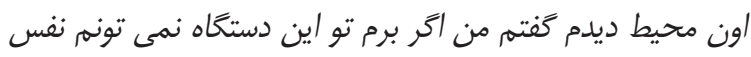
بكشم و از ترس سكته مى كنهم ولى بعلش همونى كه مى خواست ازمن عكس برداره كلى واسم توضيح داد كه اين دستخاه جِيه ومنو

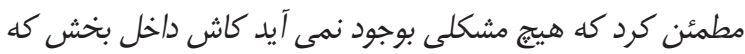
بودم يكى واسم اين توضيحات رو مى داد كه اين ترس رو نداشتم و

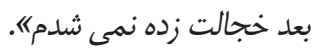
اكثر مشاركت كنندگًان از هم اتاقى با بيماران بد حال كَله مند

در اين زمينه سالمندى SV ساله اظهار داشت : \ا از روزى كه بسترى شدم و كنارم يك بيمار بل حال بوده بلتر شدم، با اين همه دم ودستخاه كه بهش وصل بود و سروصدايى كه داشت نتونستم يكى ساعت راحت بخوابم بعلش هم كه خيلى بد حال شده بود هر 


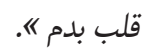

ه- مسائل مرتبط بـ تغذيه

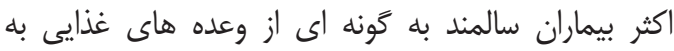
خصوص شام ناراضى بودن بعضى از سالمندان نيز از طولانى بودن

مدت ناشتايى شاكى بودند. در اين خصوص بيمارى اظهار كرد:

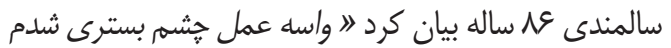

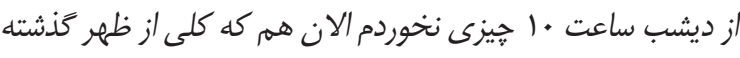

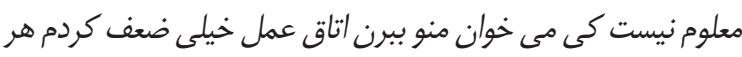

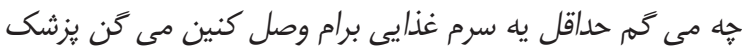

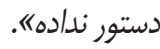

در خصوص كيفيت غذا سالمندى عنوان كرد: "جهارده روزه بسترييم واسه اجابتم مشكل دارم دكترم ميخه

ميوه و سبزيجات بخور اخه مكاه اينجا از اين جور حيزا ميدن... "

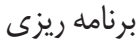
بعد از شناسايى مشكلات سالمندان بسترى در بيمارستان در مرحله برنامه ريزى جهت نخرش تيم مراقبت و ارائه مراقبت مطلوب داني و با كيفيت و موانع آن كروه متمركز كه شامل كا بانفر از تيهم مراقبتى

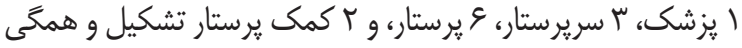
در بخش هايى بودند كه به كونه اي با بيماران سالمند در ارتباط

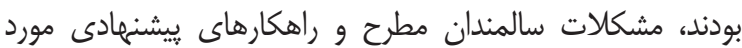

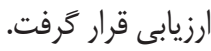

بحث در گروه متمركز مناسبترين روش استفاده هدفمند از

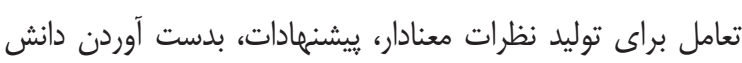
جديد و يا ارزيابى خدمات و برنامه مى باشد. قدرت واقعى از تمركز كروه براى ارائه ديدكاههاى شركت كنندكان، رفتارهاى بيجيجيده و

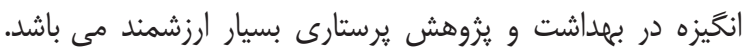

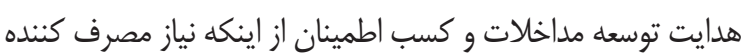
(بيماران) را تأمين كند در كروه متمركز وجود دارد (ب) (1). كروه هاى متمركز در تحقيقات يرستارى با هندين هدف از

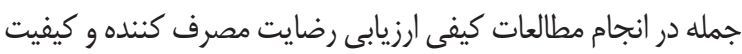
مراقبت، كمك به تصميم گيرى حرفه ای، بررسى و كشف مشكلات مراقبت از بيمار و راهبردهاى توسعه مداخلات مؤثر مورد استفاده قرار كَرفته است (ب) (1). يس از هماهنگ

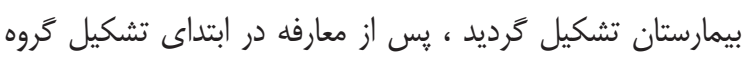
متمركز تيه مراقبتى هدف از تشكيل گَروه، تمامى مشكلات و متن

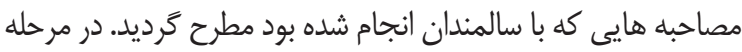
اول از يكايك اعضاى كروه خواسته شد آزادانه و صريح عقايد و
مهام هستيم و احترام از سوى يزشكان و يِرستاران موجب دلكَرمى و اعتماد انها مى شود و از بى توجهى بعضى از يرستاران شاكى و كله

سالمندى VA ساله بيان كرد : اخدا بإر ومادر همه اونهايى كه به ما خدمت مى كنند بيامرزد، اونا حضرت عيسى كه نيستند شفا

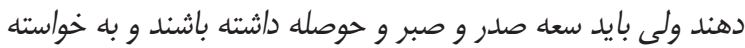
هاى ما توجه كنند". ع أ كمبود تسهيلات براى بهبود رفاه بيمار تسميلات و برخوردارى از امكانات رفاهى يكى از مسايلى بعلى

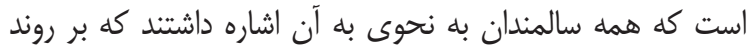

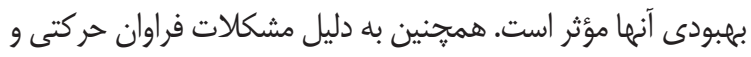
جسمى جابه جايى و انتظار كشيدن براى امور تشخيصى، درمان براى سالمندان بسيار سخت و غير قابل تحمل مى باشد. سالمندى V9 ساله عنوان كرد :التوى اين هواى سرد منو دو بار بردن اون سر بيمارستان واسه عكسبردارى و سونوكرافى كه هر دو دوال شون توى يك قسمته كاش همون دفعه اول هر دو تاشون انجام مى

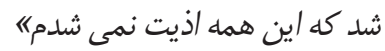
به ايمنى و رفاه بيمار توجه كافى نشده است در اين زمينه سالمندى عN ساله بيان كرد: "جند روزه روى اين تخت خوابيدم

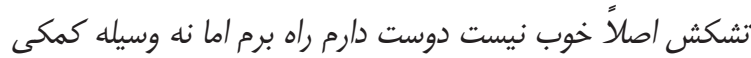
است نه كسى كمكم مى كنه البته سرشون خيلى شلوغه توى راهرو

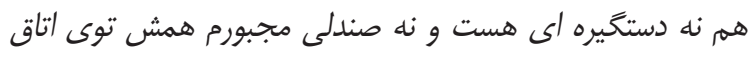
باشمر צ- ناخرانى در برداخت هزينه هاى درمانى با توجه به وضعيت نابسامان اقتصادى افراد و افزايش هزينه هاى مراقبتى و درمانى اكثر سالمندان براى يرداخت هزينه هاى

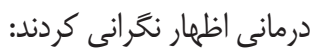
سالمندى سٓ ساله بيان كرد 》 اكه مرخص بشم نمى دونهم به خه يولى تسويه حساب كنه، داروها رو بخيرم، تازه يشتم هم زخم شده به همراهم كفتند بايد يك يانسمانى رو تهيه كنى كه زخم زودتر

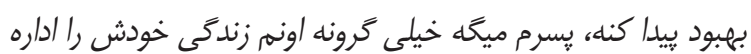

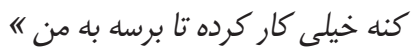
بيمار سالمندى هو ساله كه به طور سريايى به درمانكاه تخصصى مراجعه كرده بود بيان كرد: الز ساعت ه صبح توى اين هواى سرد براى كرفتن نوبت كردان اومدم درمانكاه /ونايى كه جوون و با سواد بودن خودشونو انداختند جلو من كه آخرش نفهميدم نوبت ها خه جورى تموم شد وضعيت مالى

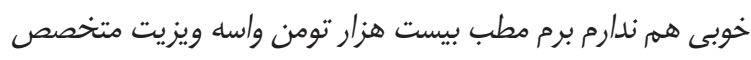




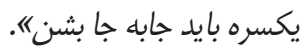

سريرستار بخش داخلى با سابقه ل| كار سال بيان كرد: العدم نوشتن تشخيص توسط يزشك معالج در يرونده بيمار

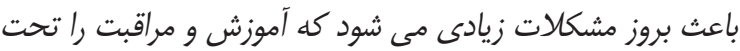

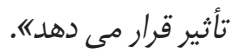

در زمينه وجود بيماران بدحال در كنار بيماران ديخر يرستار

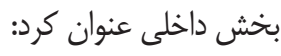

"جابه جايى بيماران خيلى مشكل است و كمبود تخت نيز

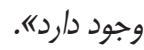

اكثر بيماران بخش داخلى به علت كمبود تخت قبل از بهبودى

ترخيص ميشن هنوز يه هفته نشده برمى كردن".

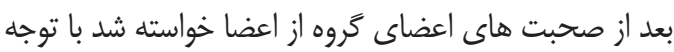
به مسايل و مشكلات عنوان شده هر تونه راهكار وض يشنهادى كه براى حل اين مشكلات و رضايت سالمندان دارند عنوان كنند. در گروه متمر كز تشكيل شده افراد هيج كَونه مقاومتى در زمينه مسايل مطرح شده نداشتند و اكثر افراد دوست داشتند مشار كت كنند و انخيزه جهت تغيير و حل مسايل در آنها وجود داشت. ييشنهاداتى كه توسط گروه متمركز عنوان گرديد و راه حل هايى كه توسط محقق در حين يزوهش شناسايى شد به شرح

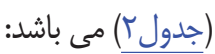

احساسات و رفتارهاى خود را ابراز نمايند،در اينجا به برخى از كَته هاى اعضاى كروه متمركز اشاره شده است:

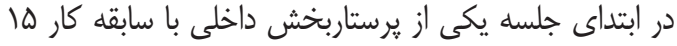

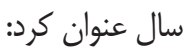
لهميشه تخت هاى اين بخش بر است به طور ميانكَين

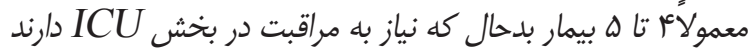
در اين بخش بسترى هستند در هر شيفت هم كه بّ برستار، يك كمكى ويك خدمات مى باشد خيلى از بيمارها هم كه همراهى ندارند

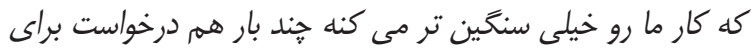

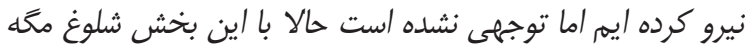
مى تونيم مراقبت با كيفيت انجام بديم يا وقت داريم به بيماران

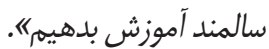

يرستار بخش اورزانس با سابقه كار 1 سال عنوان كرد: |اكر در حين انجام اقدامات مراقبتى با سالمندان ارتباط برقرار كرده حتى با يك سلام و احوال يرسى كوتاه اعتماد آنها را جلب إنباط برتي

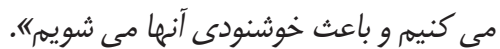
كمك يرستار بخش داخلى با سابقه كار 9 سال كه در كروه

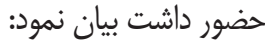

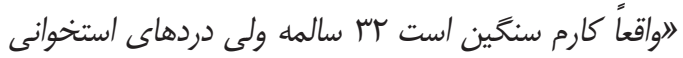

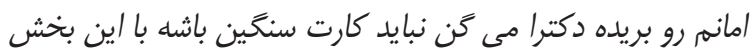

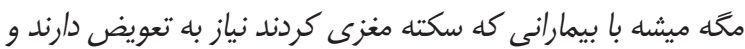

\begin{tabular}{|c|c|}
\hline 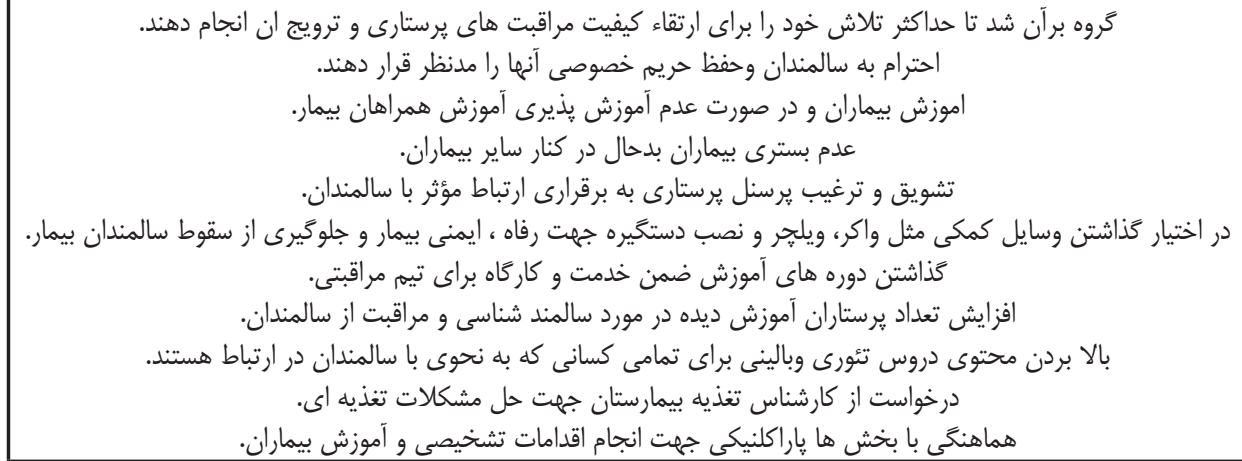 & $\begin{array}{l}1 \\
r \\
r \\
r \\
0 \\
\text { r } \\
\text { v } \\
1 \\
9 \\
1 . \\
11\end{array}$ \\
\hline
\end{tabular}

جدول r: ييشنهادات و راه حل هاى شناسايى شده

تختها به نرده و درخواست واكر، نصب دستخيره در راهرو و دستشويى

جهت رفاه، ايمنى سالمندان و گذاشتن صندلى در راهروى بخش. ه- اختصاص اتاق براى بيماران بد حال در بخشهاى داخلى سئ

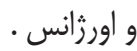

צ- توجيه پرسنل و تشويق پرسنل به برقرارى ارتباط مؤثر،

محترم شمردن و حفظ حريم خصوصى بيماران. -V هماهنگَى با مددكار اجتماعى بيمارستان و عنوان كردن مشكلات مالى سالمندان در طى درمان و ترخيص.

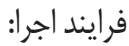

1- دراين مرحله با مديريت خدمات يرستارى جهت افزايش

نيروى يرستارى هماهنخَى لازم به عمل آمد. r- يس از موافقت سويروايزر آموزشى مجوز كاركاه جهت تيهم مراقبتى در رابطه با سالمند شناسى و مراقبت ها مربوطه گرفته شد.

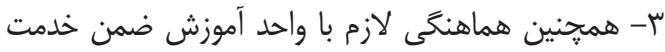

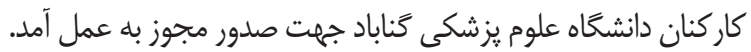
ץ- هماهنخى با سريرستار بخش هاى مربوطه جهت تجهيز 
داروسازان و متخصصين بهداشت روانى طراحى و نظارت بر افراد مسن حداقل هر شش ماه با پشتيبانى تيم رشته هاى مختلف و در صورت نياز ارجاع سالمندان به مراكز تخصصى مراقبت ضرورى مى نى ني

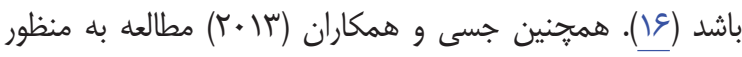
بررسى الحوهاى مراقبت و كيفيت از افراد مسن انجام دادند كه نشان اندان داد بازَّت افراد مسن و بسترى مجدد در يك دوره كوتاه زمان ظرف VI ساعت ديده مى شود كه اين ممكن است به علت كاهش

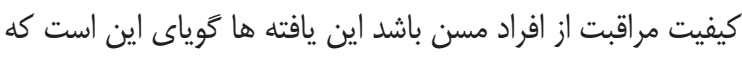

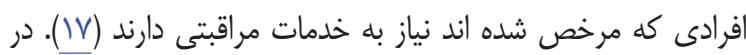

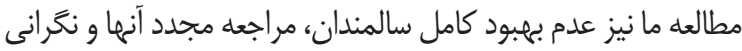
خانواده ها جهت مراقبت از سالمندان ديده شد و همجِنين بهبود

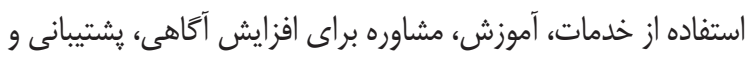

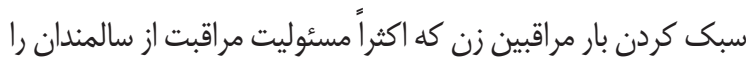

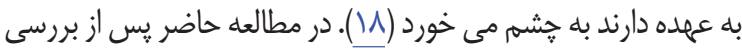

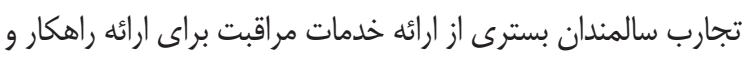

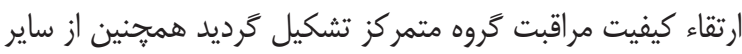
تيم مراقبتى كه در كروه حضور نداشتند درخواست كرديد با ارائه راهكار و همكارى ما را در انجام اين تحقيق همراه با عمل يارى كنند

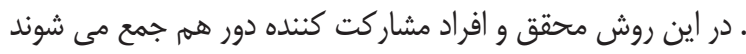

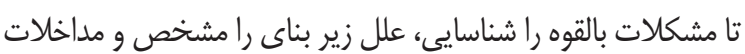

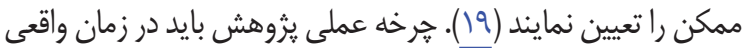
با درك درست زمينه اى از مشكل و مشكلات تشخيص داده شده باشد (م) ). در كروه متمركز و مطالعه دست نوشته هاى ساير تيم مراقبتى عوامل مؤثر مراقبت از سالمندان كه شامل شلوغى بخش هال هاء كمبود نيروى يرستارى، اختلال شنوايى و فراموشى سالمند، كاهش

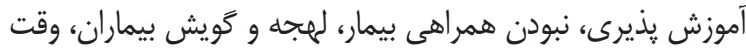

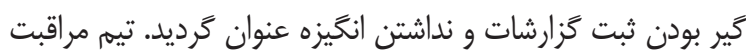
بايد به كسب دانش و مهارت هاى روانى اجتماعى مبتنى بر آكاهى، ارتباطات و درمان دست ييدا كنند. آموزش ييرى شناسى در يزشكى و يرستارى بسيار محدود مى باشد. همجنين بيمار ان سالمند در نبودن يزشكان متخصص سالمندى عوارض جانبى كه منجر به استفاده بيشتر از منابع مراقبت هاى بهداشتى باشد را تجربه مى كنند (آل). در يثوهش حاضر عدم همكارى بعضى از مسؤلين به علت كمبود

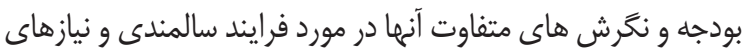
جسمى و روحى اين قشر آسيب يذير مشاهده كرديد.

\section{نتيجه كَيرى نهائى}

شركت كندكان در اين اقدام يُروهى تا حدودى توانستند
^- درخواست از مديريت خدمات يرستارى دانشگاه جهت يبيخيرى مشكلات عديده سالمندان و مراقبان انها و بيان ان در جلسات دالشخاهى و جلب همكارى ساير نهاد ها. 9- در خواست از معاونت بهداشتى و معاونت درمان براى تشكيل تيه مراقبتى و ارايه خدمات يزشكى، يرستارى براى سالمندان در منزل و تاسيس مراكز مراقبت روزانه و نظارت بر آن. •- جهت بررسى مشكلات تغذيه اى بيماران سالمند هماهنگ لازم با كارشناس تغذيه بيمارستان صورت كرفت. مقرر شد ترجيحات تتذيه اي سالمندان مدنظر قرار كيرد. 11 - هماهنكى سريرستاران با يزشكان جهت عدم تداخل ويزيت ها با هم. rا - درخواست از رياست بيمارستان جهت برقرارى مجدد

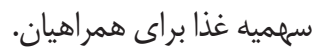

\section{كقث}

در اين مطالعه كه با استفاده از روش اقدام يزوهى به

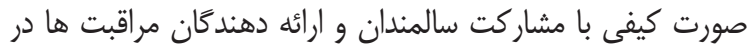
بيمارستان זٓ بهمن انجام گرفت، مشخص كرديد، برخى از نيازهاى مراقبت سالمندان بسترى در بيمارستان ناديده گرفته شده اند. كه به

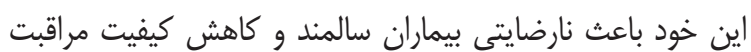

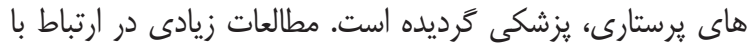
اين موضوع انجام شده و بيان داشتند كه بى توجهى به קاسخخكويى نيازهاى مراقبت شونده و محروم كردن بيماران از اساسى ترين نيازها مثل احترام، برقرارى ارتباط، آموزش درست، تغذيه و امكانات رفاهى مى تواند به علت مديريت ضعيف، حجم كار زياد و فرسودىى شغلى تيم مراقبت باشد كه با مطالعه ما همخوانى دارد (I) (I). تراين

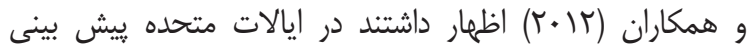
مى شود بيش از r ميليون تخت جهت مراقبت از سالمندان بيمار نياز خواهد بود، با افزايش سن سلامت نيز كاهش مى يابد و هزينه هاى

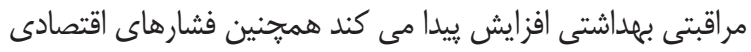
و بيجيجيدَّى مراقبت قابل توجه مى باشد بايد انتقال اطلاعات جهت بهبود و تداوم مراقبت و ايمنى بيمار سالمند در سراسر زنجيره مراقبت

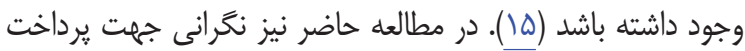
هزينه هاى دارويى، درمانى و عدم تداوم مراقبت از سالمندان بيمار مشاهده شد. مدل مراقبت يكيار קهه براى افراد مسن شامل شبكه هاى ارائه دهنده سازمان يافته با نيازهاى مبتنى بر شواهد متشكل از يزشكان،

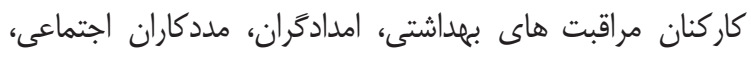




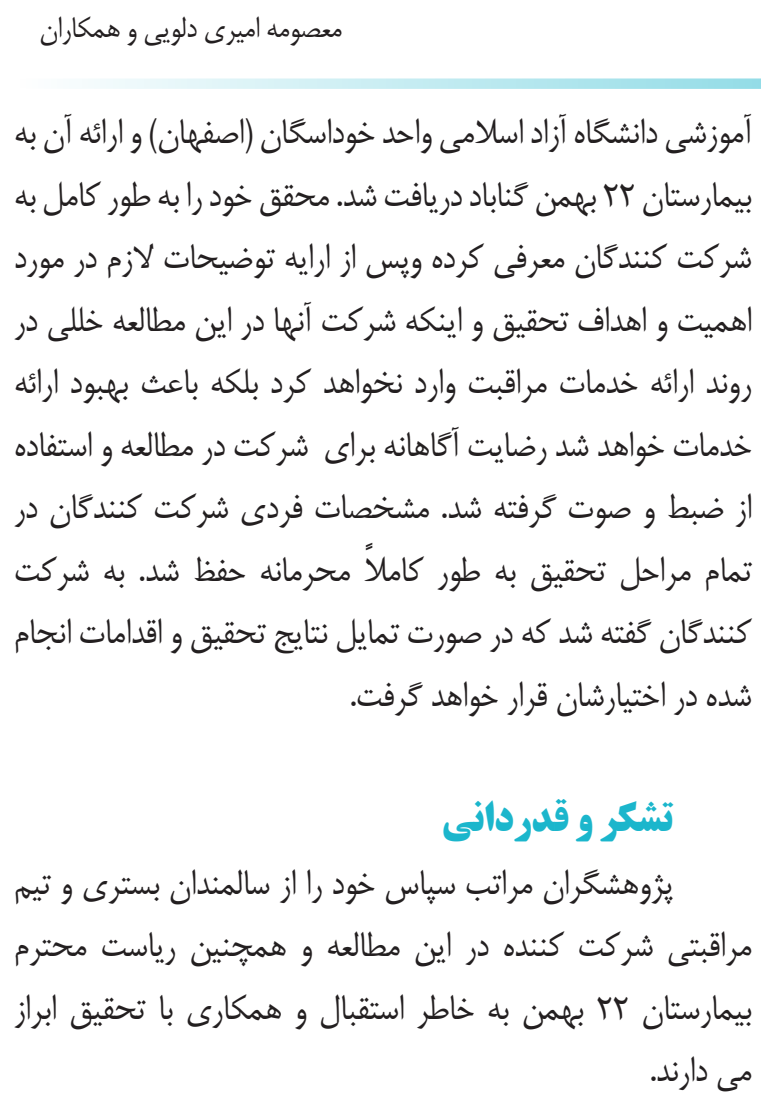

\section{References}

1. Khosbin s, Radpvyan L, Azizabadi Farahani, A. Alizadeh,M. The comprehensive geriatric care, special education guide non-physician integration of Health \& Medical Education Department of Health Bureau of Family Health multitude of health of the elderly. 2009; p:107.

2. Abedi $\mathrm{H}$, Mostafaviarani $\mathrm{F}$, Mohed rigi $\mathrm{H}$. The elderly perception and views on their health -facilitating and inhibiting factors in elderly health care in iran: a qualitative study. Journal of Procedia Social and Behavioral Sciences, 2010; 5: 2222-2226.

3. Wild B,Lechner S,Herzog W. Reliable intergrative assessment of health care needs in elderly persons:The intermed for the eldely (IM-E).Journal of Psycho Somactic Reaserch 2011:178-169.

4. Alizadeh M, Matthews CE, S. Hussein. Evaluate the use of medical and elderly care services based on health indicators Journal of Hospital Administration Hospitals
مداخلات لازم جهت ارتقاء كيفيت مراقبت هاى يرستارى، احترام و برقرارى ارتباط مؤثر و افزايش انخَيزه تيه مراقبتى را ارتقاء دهند همجنين امكانات لازم جهت ايمنى ورفاه سالمندان بسترى، اختصاص اتاق براى بيماران بدحال، درخواست از مسئولين جهت التهن افزايش نيروى يرستارى صورت يذيرفت و ترجيحات تغذيه ایى

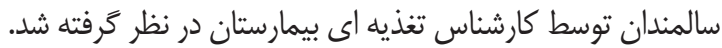
با اين حال بايد زمينه بهينه سازى و آموزش كادر يزشكى

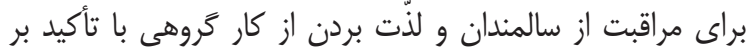
مهارتهاى ارتباطى براى بهبود نتايج و كاهش ناميدى براى سالمندان

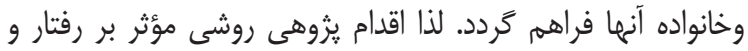
انخَيزه تيهم مراقبتى با مشار كت سالمندان بيمار و بهببود ارائه خدمات مراقبتى مى باشد كه در نتيجه كاهش نارضايتى سالمندان بسترى را در يى دارد. ارزشيابى دقيق در فرايند تغيير نياز به زمان طولانى و باني مصاحبه مجدد با سالمندان بسترى و تيمم مراقبتى دارد وخرخه اقدام يزروهى تا زمان رسيدن به نتايج مطلوب بايد ادامه يِيدا كند.

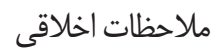
به منظور رعايت ملاحظات اخلاقى مجوزهاى لازم از معاونت

Association's official organ tenth year, 2011; 1:36 Number. 34-29.

5. Karlsson S, Edberg KA,Hallberg RI.Professional's and older person's assessment of functional ability ,health complaints and received care and service.A descriptive study.International Journal of Nursing Studies 20101217-1227.

6. Fabbrico tri NI ,Jance B, Looman WM.Integrated care for frail elderly compared to usual care:a study protocol of a quasi-experiment on the effects on the frail elderly, their caregivers, health professionals and health care costs.Journal Bmc Geriatrics. 2013.

7. Lowry DS. Aging,social change, and elderly well-being in rural china:insights from mixed -methods village research. Pupulation Studies Center University of Michigan, 2009: 09-691.

8. Asady Noghabi or, Alhani F, Peyravy H. Health in the elderly: a review. Journal of Nursing Care Research Center, Tehran 
University of Medical Sciences, 2012; 25 (78): 62-71.

9. Espyshryalh, Carpenter D. Qualitaitive research in nursing translate. Khachyan M, Shaukati D, Tehran: salemi 2010; p 432.

10. Mohammadi M, Abdy. chgvnh can be improved using close saction in the intensive care unit? First Conference on Regional Innovation in Nursing and Midwifery students of Islamic Azad University (Isfahan) School of Nursing and Midwifery, 2011; p. 563-555.

11. Atashzadeh F, Hosni P.Action research: a way to improve the quality of nursing services Nursing Research Journal 2011; Vol. 6 ,21: 58-48.

12. Rasika S, Jayasekara RN. Focus groups in nursing reaserch: methodological perspectives.Journal Nursing Outiook. 2012 60: 411-416.

13. Grove, Susan K, Dehghan nayyeri, N. The practice of nursing research: conduct, critique, and utilization, 5th ed, 2005.

14. Reader TW, Gillespie.Patient neglect in healthcare institutions:a systematic review and conceptual model Bmc Health Services Research $2013 ; 13: 156$ page 2 of 15.

15. Threan, BairB,Mullin S. Weir RC. Characreriziag, in foromation transfer. by using joint cognitive systems model to improve continuity of care in the aged international Journal of Medical in formatics 2012. 435-441.

16. Fabbrico tri NI ,Jance B,Looman WM. Integrated care for frail elderly compared to usual care:a study protocol of a quasiexperiment on the effects on the frail elderly ,their caregivers, health professionals and health care costs.Journal Bmc Geriatrics. 2013.

17. Jesse m, Pines, MD, Peter M, James k, Lise B, Katalin E.National Trends in Eme gency Department Use, Care patterns, and
Quality of care of older Adults in the united States Jounnal Compilation the American Geriatrics Society 2013;61: 12-17.

18. ludecke D, Mnich E, Kofahl C. The impact of sociodemographic factors on the utilization of support services for family caregivers of elderiy dependents-results from the german sample of the eurofamcare study. Gms Psycho-Social-Medicine, 2012; 9: 1860-5214.

19. Doosti Irani,M. Abdoli,S. Parvizi,S. Amin,M. An Umbrella Named Action Research, Iranian Journal of Medical Education,2011;11(9)1223-1230.

20. Moore O, Crozier k, kite k .An action reaserch approach for developing reaserch and innovation nursing and midwifery practice: bulding reaserch capacity in one NHS Foundation Trust Journal Nurse Education Today. 2012; 32: 39.

21. Shoshana H, Bardach MA, Grahamd: Geriatric Education in the health Professions Arewe Making progress? Journal as: the Gerontologist2012; 607-618. 